\title{
Market concentration and profitability: the empirical evidence from Serbian manufacturing industry $^{* 1}$
}

\author{
Radovan Kastratović ${ }^{2}$, Dragan Lončar ${ }^{3}$, Siniša Milošević ${ }^{4}$
}

\begin{abstract}
The impact of market concentration on profitability is a controversial question in industrial organization without a clear answer. The aim of the research is to investigate this prospective impact in the context of Serbian manufacturing industry. The main hypothesis of the research is that the increase in market concentration increases the profitability in the markets, due to the collusion of the dominant companies. We test this hypothesis by defining, estimating and testing the model describing the impact of structural and other control variables on market profitability by using secondary panel data for 122 markets, observed in 2015 and 2017. We obtained the data from 30037 financial reports of the manufacturing industry companies. The model was estimated by using an error component two stage least squares estimator (EC2SLS). The results indicate a statistically significant positive impact of market concentration on profitability, empirically supporting the traditional market power hypothesis.
\end{abstract}

Key words: market concentration, profitability, competition, collusion, manufacturing

JEL classification: D43, L11, L41

* Received: 10-07-2018; accepted: 16-01-2019

1 Authors declare no relevant or material financial interests that relate to the research presented in this paper.

Acknowledgements: We would like to thank the Editor and the anonymous reviewers for their helpful comments and suggestions. We would also like to thank Prof. Goran Petković, for his helpful comments on an earlier version of the manuscript. Any errors remain those of the authors.

2 Analyst, Institute for Business Research - MBA, Dubrovačka 24, 11000 Belgrade, Serbia. Scientific affiliation: international economics, industrial organization. Phone: +381 11203 0002. Fax: +381112928 015. E-mail: radovan.kastratovic@institutmba.co.rs. Website: https://www.institutmba.co.rs/ (corresponding author).

${ }^{3}$ Full professor, Faculty of Economics, University of Belgrade, Kamenicka 6, 11000 Belgrade, Serbia. Scientific affiliation: strategic management, project management, competition. Phone: +381 11302 1075.E-mail: loncar@ekof.bg.ac.rs.Website: http://www.ekof.bg.ac.rs/loncar-dr-dragan/.

${ }^{4}$ Chief economist, Commission for Protection of Competition of the Republic of Serbia, Savska 25, 11000 Belgrade, Serbia. Scientific affiliation: competition, industrial organization. E-mail: sinisa.milosevic@kzk.gov.rs.Website:http://www.kzk.org.rs/ 


\section{Introduction}

Market competition is a requirement for efficient resource allocation in any economy. It is usually desirable, as it spurs innovation, efficiency and better fulfillment of consumers' needs (Vives, 2008). As the competition is difficult to measure in practice, one possibility to analyze it is to observe the market concentration, which approximates market structure (Gal and Cheng, 2016).

The impact of market concentration on profitability has been researched in industrial organization literature. Yet, there is still no consensus regarding the nature and modus of this impact. In theory, this impact can be positive, negative or insignificant. Positive impact is usually explained by one of the two conflicting hypotheses: market power hypothesis or efficiency hypothesis. According to the market power hypothesis, market concentration has a positive impact on profitability, due to collusion and the abuse of market power by dominant companies (Bain, 1951). Conversely, efficiency hypothesis assumes that the relationship between market concentration and profitability is, in fact spurious, as the efficiency of dominant companies is a common antecedent to both variables (Demsetz, 1973). There are also theories predicting a negative impact of market concentration on profitability (Leibenstein, 1966; Keil, 2017). Finally, some theories integrate both possible outcomes (Lee and Mahmood, 2009), whereas some theories claim that the variables are entirely unrelated (Brozen, 1971). The empirical results appear to be similarly mixed.

The purpose of this research is to investigate the prospective impact of market concentration on profitability using the data on Serbian manufacturing industry. Furthermore, we seek to describe the nature of such impact and to examine if it reduces the intensity of competition. The main hypothesis of the research is that the increase in market concentration levels of the markets comprising the manufacturing sector of Serbia on average increases market profitability margins. We test this hypothesis by using a unique panel dataset obtained from the 30037 financial statements of the companies which comprise the manufacturing industry sector of Serbia. We apply the instrumental variable approach for panel data, using an error component two stage least squares estimator to estimate the model describing the impact of structural determinants on market profitability, while accounting for endogeneity due to the simultaneity in the variables' relationship. As the prospective positive impact of market concentration on profitability cannot be a priori considered as desirable or undesirable, we also investigate the possible causes of it.

The results of model estimation provide another piece of empirical evidence which contributes to the understanding of the relationship between market structure and performances. Additionally, the research results might explain how different factors affect market profitability, which could have important implications for the implementation and revisions of competition policies, especially in the Republic of Serbia. 
The article is organized as follows. The second section provides a short review of the related research. The third section describes the applied methodology, the model and its variables. In the fourth section, we describe the data used for model estimation and present the most important empirical results. In the fifth section we discuss the theoretical and practical implications of the obtained results. The final section concludes.

\section{Literature review}

A large body of industrial organization literature investigated the impact of market structure on market agents' behavior. Mason (1939) was one of the first authors to explore the relationship between market structure and market performances, predicting a positive relationship between the variables from a profit maximization problem of the individual firm. Developing Mason's idea and lifting the analysis perspective to industry-level, Bain (1951) defined the market power hypothesis. According to this hypothesis, markets with higher market concentration have higher average profit rates, assuming that the higher market concentration facilitates the collusion between the dominant companies. This hypothesis was further developed and formalized by Cowling and Waterson (1976). An alternative explanation for the seemingly positive relationship between market concentration and profitability was provided by Demsetz (1973). His efficiency hypothesis states that positive correlation of market concentration and profitability is not necessarily a consequence of anticompetitive behavior. The correlation between market concentration and profitability could be spurious, as both variables have a common antecedent - the efficiency of companies. If that is the case, the competition policy preventing market concentration would not be adequate, as the innovative companies with superior efficiency would essentially be punished.

In contrast to previously discussed theories, some theoretical models predict a negative relationship between market concentration and profitability. Such relationship can be explained with X-inefficiency - the loss of motivation to reduce costs by the market leaders in the absence of the strong competitive pressure (Leibenstein, 1966). Another explanation for the potential negative are the excess production capacities present in a particular industry (Spence, 1977). Lock-in model also predicts a negative relationship between the variables, explaining it as a consequence of sunk costs, caused by the high levels of fixed capital which trap the companies in unprofitable industries (Keil, 2017).

In addition, Brozen (1971) presented a theory implying that market concentration and profitability are entirely unrelated. Finally, Lee and Mahmood (2009) attempted to formulate a model integrating both positive and negative relationship between market concentration and profitability. According to their model, market 
profitability is determined by: strategic investment, market concentration, the level of strategic investment protection and the degree to which market share determines strategic investment intensity.

Comparable to the theoretical literature, the results of empirical research investigating the relationship between market concentration and profitability have not been consistent. The majority of the results indicate a positive impact. In contrast, there are comparatively fewer studies which report negative impact of market concentration on profitability (Anderson et al., 2000; Alhassan et al., 2015; Mukhopadhyay and Chakraborty, 2017). Additionally, some studies do not find any statistically significant relationship between market concentration and profitability after controlling for other profitability determinants (Clarke, 1984; Khan and Hanif, 2018; Keil, 2018).

Decades after Bain's seminal work, empirical research on the impact of market concentration on profitability was conducted only in developed countries (particularly the United States, Canada and the United Kingdom), using a crosssectional approach, ordinary least squares methodology and Structure-ConductPerformance theoretical framework. The majority of these studies report a positive relationship between market concentration and profitability (Collins and Preston, 1969; Strickland and Weiss, 1976). A notable exception is the study by Clarke (1984), which did not indicate a statistically significant relationship between market concentration and profitability.

As the data became more readily available, researchers started investigating this problem in the context of manufacturing industries of both developed and developing countries (particularly India), using panel data methodology and reporting rather mixed results. One of the first authors to use dynamic panel methodology in this context was McDonald (1999), whose study indicates a positive relationship between market concentration and profitability of manufacturing industries in Australia. The studies observing manufacturing industries of India indicate not only positive or insignificant but also a negative relationship between the variables, depending on the methodology used and the observed period. For instance, Bhandari (2010) found a positive relationship between market concentration and profitability using static panel methodology, whereas Mishra (2008) and Mukhopadhyay and Chakraborty (2017) used dynamic panel data methodology, and found insignificant and negative relationship, respectively. Positive relationship was also found in manufacturing industries of Indonesia (Setiawan and Efendi, 2016). Researchers also observed the problem in the wider context of all industries (rather than only manufacturing). This line of research mostly combines panel data with instrumental variables approach. For instance, Keil (2018) observed the economy of the United States and did not find a statistically significant relationship between market concentration and profitability, while Gallagher et al. (2015) found a positive relationship in the case of Australia. Similar research undertaken in Mongolia indicates a negative relationship between the variables (Anderson et al., 2000). 
Another line of inquiry about this problem focuses on more narrowly defined industries and observes either industry of firm level in both developing and developed countries, using either a cross-sectional or panel data approach. Food industry has been of a particular interest to researchers. Employing two-stage least squares methodology, Stiegert (2009) found a positive relationship between market concentration and profitability. Similar results were obtained by Pervan and Mlikota (2013) in the case of Croatia using a dynamic panel methodology and Blažková and Dvouletý (2017) for Czech Republic using a static panel methodology. Insignificant results were found by a cross-sectional research in the case of wine industry of Canada (Outreville, 2015). Apart from food industry, researchers observed a variety of other industries, mostly using panel data methodology. Market concentration and profitability were not found to be related in financial services industry of Ghana and Pakistan (Alhassan et al., 2015; Kahn and Hanif, 2018). Li et al. (2017) also found no statistically significant relationship in Chinese solar panel industry, using a static panel methodology. Finally, Škuflić et al. (2018) found a statistically significant positive relationship in construction industry of Croatia, using dynamic panel methodology.

The research of the impact of market concentration on profitability in the context of Serbia is limited to case studies of narrowly defined industries. For instance, Stojanović and Kostić (2013) found a positive relationship between market concentration and profitability in the case of beer industry, using a cross-sectional approach, while Lončar et al. (2016) provide empirical evidence supporting the market power hypothesis in the case of banking sector. As the focus of the aforementioned studies is narrow, the possibilities of a broader generalization of the results are limited. This research aims to contribute to the existing literature by observing a large number of markets comprising manufacturing industry sector of Serbia, using a unique dataset of Serbian companies' financial statements. By doing so, it provides additional empirical evidence and allows the identification of more general empirical regularities regarding the relationship between market concentration and profitability, taking the specific characteristics of the individual markets into account.

\section{Methodology}

The research analyses the impact of market concentration on profitability using secondary panel data. We observe 122 markets in years 2015 and $2017 .^{5}$ The markets are defined as narrowly as the available data allowed. The aim was to investigate the possible impact of different structural market characteristics on market profitability.

\footnotetext{
5 These particular years were chosen because of data considerations.
} 


\subsection{Empirical model}

We apply econometric methodology in the research to determine statistical significance and quantify the impact of the independent variables. The starting point of our empirical model specification is the Structure-Conduct-Performance paradigm (Bain, 1951, 1956; Cowling and Waterson, 1976), according to which market profitability $(\pi)$ is functionally dependent market concentration $(\mathrm{C})$, market entry barriers (B) and other heterogeneous market characteristics $(\mathrm{O})$ :

$$
\pi=f(C, B, O)
$$

Before the model being further developed, it is necessary to precisely define what is understood by the term market, used in this general model. The definition consists of two main components: product component and geographic component.

In this research, relevant market was defined by taking into account theoretical requirement and data availability. We assumed that all the analyzed product markets perfectly correspond to statistical four-digit industries defined by the Statistical Classification of Economic Activities in the European Community (NACE revision 2) and encompassed by the general class of manufacturing sector. Such definition does not fully comply with the theoretical requirements. It implicitly assumes that all the markets geographically refer to the territory of the Republic of Serbia, neglecting possible local monopolies. Nevertheless, given the size of the territory of the Republic of Serbia, it does not seem plausible in most cases that the geographical distance of the production capacities can prevent the companies from reaching customers in all parts of the territory. Another problem is that companies can also export a part of the output, which may lead to the overestimation of the concentration indicator. Finally, companies can produce different products which do not necessarily match the statistical industry code in which the company is registered. Even though the market definition used in the research does not fully meet theoretical requirements, and represents a mere approximation of the theoretical markets, we had to make a compromise due to the nature of the available data used for the variables operationalization and model estimation.

Profitability is the dependent variable in the model. In the traditional StructureConduct-Performance paradigm it is operationalized as accounting market-level profit rate (Bain, 1951, Cowling and Waterson, 1976, Schmalensee, 1989). In this research, we measure market profitability as market-level net profit margin, following the approach of Clarke (1984), McDonald (1999) and Pervan and Mlikota (2013). It was calculated by dividing the sum of net profit (or losses) of all the companies in a particular market and the sum of all the companies' revenues in the same market. Using any accounting-based profitability measure is problematic, as large companies could produce many products which correspond to different markets, despite being registered in certain statistical industry class. Companies 
may also reduce their tax burden by reporting profits in financial statements which are lower than the actual levels. In addition, by using accounting data from publicly available financial reports, the analysis systematically excludes gray economy, which according to some estimates equals between $21 \%$ and $30 \%$ of Serbian gross domestic product (Foundation for the Advancement of Economics, 2013). This might reduce the precision of the measures based on the accounting data. For these reasons, the measurement of profitability is likely to be different from theoretical profit, to which hypothetical market concentration impact refers. Still, as pointed out by Bain (1951), in sufficiently large number of observations, price changes and theoretical profit will on average have a similar effect on accounting profit and the profitability measures employed in the research, which should even out any individual irregularities.

Independent variable in focus of this research is market concentration. It can be measured with two types of indicators: discrete (observing only the largest producers) and cumulative (observing all producers). As Lee and Mahmood (2009) point out, cumulative indicators are the most suitable independent variable in empirical models describing the impact of market concentration on profitability, because the underlying theoretical models explicitly determine profitability by market shares distribution asymmetry. Besides, the advantage of this indicator is the increased precision. Therefore, we opted for using a cumulative indicator, namely Herfindahl Hirschman index, which is an operationalization of market concentration suggested by the model of Cowling and Waterson (1976), and was recently used by Mukhopadhyay and Chakraborty (2017), Keil (2018) and Škuflić et al. (2018).

In the empirical literature there are two methods of calculating Herfindahl Hirschman index: revenue-based and asset-based. We employed both methods in this research to check the robustness of the results. Revenue-based index was calculated using the following formula:

$$
H H I=\sum_{i=1}^{n} s_{i}^{2}=\sum_{i=1}^{n}\left(\frac{R_{i}}{\sum_{i=1}^{n} R_{i}}\right)^{2}
$$

as the sum of squared market shares of individual companies $\left(\mathrm{s}_{\mathrm{i}}\right)$ on individual markets, where market shares are determined as the ratio of total revenue (R) of each individual company $i$ and the sum of the revenues of all $n$ companies corresponding to the market for which the index value is calculated. Asset-based index was calculated in the same way, except that the assets values were used instead of revenue. In the literature the most common functional forms of the model are linear and quadratic. After performing curve fitting procedure for market concentration and profitability variables considering 19 functional forms (results of which are available from authors upon request), we opted for linear functional form, which proved to be the best fit for the data. We expect statistically significant 
positive impact of market concentration on profitability, regardless of the market concentration measurement used.

Market entry barriers (B) are included in our model in the form of two variables: minimum efficient scale of production (MES) and product differentiation (ADV and R\&D), which are considered an important determinant of market-level profitability in the theoretical framework of Bain (1956), as well as more recent theoretical models (Lee and Mahmood, 2009; Keil, 2017). According to the aforementioned theoretical framework, high levels of minimum efficient scale imply such technological market conditions which can only be met by few companies, which could decrease competition intensity, and increase market profitability. Minimum efficient scale is used in the related empirical work as an approximation of entry barriers due to the economies of scale. Researchers often approximate it as the size of the largest $50 \%$ of the companies on a given market, using the aggregated financial data (Strickland and Weiss, 1976; Stiegert et al., 2009; Bhandari, 2010). Such approximation was employed in this research as well. If the variable is statistically significant, we expect positive estimate of its corresponding parameter.

Traditional Structure-Conduct-Performance theory predicts that market differentiation also affect market-level profitability (Mason, 1939; Bain, 1951, 1956). In empirical literature, this variable is often decomposed into advertising intensity and research and development intensity (Mishra, 2008; Bhandari, 2010; Keil, 2017), which is the approach we adopt in this research. The advertising intensity (ADV) was measured as a ratio of advertising, distribution and related costs to sales, following the approach of Bhandari (2010) and Mukhopadhyay and Chakraborty (2017). Research and development intensity (R\&D) was measured as the ratio of total value of concessions, patents, trademarks, software and other proprietary right on one side, and total assets value on the other side. The data needed to measure advertising intensity was collected and aggregated from financial statements of all the companies for every industry in the sample, whereas the research and development intensity data was similarly collected and aggregated from balance sheets. As the product differentiation is theoretically expected to increase market profitability, we expect positive value of the coefficients for both variables.

Although potentially significant, structural variables are not the only factors determining market profitability. Markets are heterogeneous categories in which idiosyncrasies may cause the differences in profitability (Brozen, 1971). Therefore, we include a set of control variables in the model, which account for other market profitability determinants $(\mathrm{O})$ : capital intensity of the industry $(\mathrm{CI})$, financing method (F), labor productivity (LP) and energy efficiency (EE).

Capital intensity (CI) of a particular industry may impact its profitability significantly. When capital intensity is low, value added is expected to be low 
as well, which should reduce profitability. However, the highest levels of capital intensity might also lead to the reduced profitability, as such situation could indicate the companies on the market offer products in the early stages of their life cycle or the excessive use of capital (Spence, 1977). A common characteristic of transition countries such as Serbia is the existence of large underutilized industrial capacities. We construct this variable as a ratio of total assets value and total revenues of each individual relevant market, following the approach of Mishra (2008) and Stiegert et al. (2009). The variable was introduced in different specifications of our empirical model in either level or square term.

Market profitability was also controlled for financing methods of the producers, i.e. their liabilities structure. In constructing this variable, we follow the approach of Pervan and Mlikota (2013), Gallagher et al. (2015) and Li et al. (2017) using the ratio of total stockholders' equity of all the companies in a particular market and total liabilities of all the companies in the same market. Higher values of this ratio imply that the companies have fewer burdens financing their business activities, which should improve their profitability. This is why we expect positive value of the parameter estimate for this variable. In addition, market profitability was controlled for labor productivity (LP) by following the approach of Anderson et al. (2000) and Blažková and Dvouletý (2017), measuring it as value added per worker. Markets with higher value added are expected to be more profitable. Finally, many authors emphasize the need to control for efficiency of input usage (Li et al., 2017; Alhassan et al., 2018; Škuflić et al., 2018). Therefore, we include energy efficiency (EE) as control variable in the model, measured as sales to energy costs ratio. Its impact on market profitability is ambiguous. On one hand, more efficient use of energy, should reduce costs and, consequently, increase profits. However, more efficient use of energy could also indicate a less capital-intensive production, with lower value added, which should also be related to lower market profitability.

\subsection{Estimation method}

We started the econometric analysis with the most general model (in terms of the number of independent and control variables) which was possible to estimate, given the available data. This model can be expressed as:

$$
\begin{aligned}
\pi_{i t}= & \beta_{0}+\beta_{1} H H I_{i t}+\beta_{2} M E S_{i t}+\beta_{3} A D V_{i t}+\beta_{4} R \& D_{i t}+ \\
& +\beta_{5} F_{i t}+\beta_{6} C I_{i t}+\beta_{7} L P_{i t}+\beta_{8} E E_{i t}+\mu_{i}+u_{i t}
\end{aligned}
$$

Individual effects of markets which are not explicitly stated by the model are included in the error term $\mu_{i}$, while other temporary deviations of market profitability are included in the error term $\mu_{i t}$. The problem with estimating the model using the usual pooled ordinary least squares or generalized least squares 
methodology is that there is a strong possibility that profitability also affects market concentration (Schmalensee, 1989). If that is the case, the estimates using the aforesaid methodology would be biased, as the endogeneity problem would arise, due to simultaneity. Furthermore, there could be two-way causal relationship between conduct variables (ADV and R\&D) and profitability, as well as between the conduct variables and structure variables (HHI). Two-way causality between conduct and structure variables could cause multicollinearity problem leading to inefficient estimates, if market concentration and conduct variables are strongly correlated. This is not the case in our sample however, as the correlation coefficients between market concentration and advertising intensity and research and development intensity are 0.05 and 0.11 respectively, and statistically insignificant. More serious problem could arise due to two-way causality between market profitability and structure or conduct variables, which would make OLS estimates inconsistent. We test for this possible endogeneity using a test proposed by Hausman (1978), with the null hypothesis $E\left(u_{i t} \mid X_{i t}\right)=0, X_{i t}$ being the vector of independent variables. The test rejected this hypothesis at $5 \%$ significance level with test statistic $\chi^{2}(4)=10.40$, leading us to conclude that there is endogeneity due to simultaneity present in the model.

A possible solution to the endogeneity problem due to simultaneity is to employ an instrumental variable approach, namely the error component two stage least squares (EC2SLS) estimation technique proposed by Baltagi (1981). The EC2SLS estimation was compared to the alternative fixed effects two stage least squares estimator (2SLS-FE), using a Hausman test, which failed to reject the null hypothesis for all model specification considered in this paper, meaning that the differences between EC2SLS and 2SLS-FE estimates are not statistically significant and implying that EC2SLS is a preferable alternative as a more efficient of the two estimators. For this reason, we opted for EC2SLS estimator in the analysis.

As three variables (HHI, ADV and R\&D) could cause endogeneity due to simultaneous causal relationship with market profitability we provided instruments for each of them. We used two variables as instruments for market concentration: the share of equipment value in total value of assets on a market (EQ) and the level of related entities activities on the market (REA), which was measured as log-transformed total value of revenues received from related companies on each market. Both instruments were found to be positively correlated with market concentration, while having no significant correlation with market profitability. The economic reasoning for using the share of equipment value as an instrument is that the high level of the assets which are not easily transferable to other industries locks in the companies in the industries, which is a risk only few companies are willing to take, ultimately affecting the market concentration (Spence, 1977; Keil, 2017). However, the high requirements for industry-specific assets does not equal to their effective and profitable usage. The choice of the other instrument (REA) 
was motivated the fact that higher levels of activities with the related entities on a market indicates a higher propensity of companies on such market for mergers and acquisition. This directly affects market concentration. These activities, however, do not per se systematically affect the profitability, as the positive and synergic effects of mergers and acquisitions are not guaranteed (Cascorbi, 2003). Market size (S) was used as an instrument for advertising intensity, following the reasoning of Willis and Rogers (1998) that it could determine advertising intensity. The variable was not found to be statistically related to market profitability in our sample. Finally, average salary on the market (W) was used as an instrument for $R \& D$ variable, as the variable should be related to higher research and development activities (which requires a more educated and better paid workforce), while it is not directly related to market profitability. The validity of the instruments was further confirmed by the statistical significance of the instruments in the first stage regressions and the failure to reject the null hypothesis of Sargan-Hansen test of overidentifying restriction for all the specifications presented in this paper.

We examined the possible nonlinear relationship between profitability and structural and control variables by testing the linear-logarithmic and logarithmic-logarithmic models, which worsened statistical properties of the model ${ }^{\text {[ }}$. Furthermore, logtransformation of the dependent variable would be highly problematic as it would lead to systematic loss of observations, because our profitability variable often assumes negative values. For these reasons, we used linear model in the analysis. Except for the capital intensity variable, which was included in quadratic form in some specifications, all the other variables assume linear impact on profitability.

\section{Empirical data and analysis}

Statistical classification used as a framework in defining relevant markets in the research entails 230 activities which comprise manufacturing industry sector. The unit of observation is market. The data was obtained from BonitetiRS database, which stores and organizes publicly available financial statements provided by Business Registers Agency of the Republic of Serbia. The advantage of the database we use is that it allows sorting, filtering and aggregating the data according to given parameters, which allowed us to construct market-level measurements of the model variables from 30037 individual financial statements of Serbian companies registered in manufacturing industry sector in 2015 and 2017.

We had to remove 30 markets from the sample, as they did not contain any companies. We excluded additional 30 markets with terms "Other" and "Variable" in their name, as it implies that companies in those markets produce heterogeneous products, and therefore cannot be considered direct competitors. Our sample also excludes markets which consist only of unsuccessfully privatized large industrial 
companies which have filed for bankruptcy, since the factors determining the profitability of those markets are out of the scope of our analysis. Finally, we also exclude all the markets which do not meet two criteria: (1) minimal total revenue of the market of 8 million EUR, and (2) minimum 250 workers employed cumulatively. These criteria were introduced to prevent results distortion caused by too narrowly defined markets, consisting of few microenterprises, which likely do not cover the entire market of the Republic of Serbia. Previously discussed exclusions reduced the sample size to 244 observations from 122 markets and two time periods. This reduced sample was used in further analysis.

Table 1: Descriptive statistics

\begin{tabular}{|l|l|c|c|c|c|}
\hline Variable & \multicolumn{1}{|c|}{ Variable name } & Average & $\begin{array}{c}\text { Standard } \\
\text { Deviation }\end{array}$ & Min & Max \\
\hline$\pi$ & Net profit margin & 0.03 & 0.09 & -0.43 & 0.48 \\
\hline HHI & HHI index (revenue-based) & 2.62 & 2.21 & 0.12 & 9.90 \\
\hline HHI $^{*}$ & HHI index (asset-based) & 2.61 & 2.21 & 0.13 & 9.97 \\
\hline MES & Minimum efficient scale & 0.07 & 0.09 & 0.01 & 0.50 \\
\hline ADV & Advertising intensity & 0.04 & 0.02 & 0.01 & 0.14 \\
\hline R\&D & R\&D intensity & 0.02 & 0.05 & 0.00 & 0.39 \\
\hline F & The share of equity in liabilities & 0.45 & 0.16 & 0.05 & 0.91 \\
\hline CI & Capital intensity & 0.66 & 0.55 & 0.05 & 0.91 \\
\hline LP & Labor productivity & 0.53 & 1.11 & -2.24 & 7.78 \\
\hline EE & Energy efficiency & 0.44 & 0.37 & 0.03 & 2.56 \\
\hline Number of & observations & & & 244 \\
\hline
\end{tabular}

Note: HHI index and labor productivity are expressed in terms of thousands and millions respectively. All other variable are expressed in absolute numbers.

Source: Authors' calculations

We present summary descriptive statistics of the variables used in the empirical analysis in Table 1. The average net profit margin of markets comprising Serbian manufacturing industry sector $(\pi)$ equals approximately $3 \%$, but it greatly varies across the different markets, as evidenced by the standard deviation of $9 \%$. The values of revenue-based and asset-based Herfindahl Hirschman index are on average similar. Regardless of the calculation method, both the average value and the variations of the index are high. Similar situation is present in most of the other variables, except for the share of stockholders' equity in total liabilities (F), which varies steadily across the industries in around the level of $45 \%$.

Model of market concentration impact on profitability was estimated using EC2SLS method. Empirical results are presented in Table 2. In estimation we used 
two different measurements of market concentration: the revenue-based (columns 1-3) and asset-based (columns 4-6) Herfindahl Hirschman index. Other than the base model (columns 1 and 4), we estimated a model with quadratic form of capital intensity variable (columns 2 and 5) and a model excluding MES variable ${ }^{6}$ (columns 3 and 6). The estimator we used provides the estimated standard errors which are robust to heteroskedasticity and autocorrelation.

Table 2: Estimation results

\begin{tabular}{|c|c|c|c|c|c|c|}
\hline \multirow{2}{*}{ Variable } & \multicolumn{6}{|c|}{ Profit margin $(\pi)$} \\
\hline & (1) & (2) & (3) & (4) & (5) & (6) \\
\hline HHI & $\begin{array}{c}0.019^{* * *} \\
(0.005)\end{array}$ & $\begin{array}{r}0.019^{* * *} \\
(0.006)\end{array}$ & $\begin{array}{c}0.012^{* * *} \\
(0.004)\end{array}$ & & & \\
\hline $\mathrm{HHI}^{*}$ & & & & $\begin{array}{c}0.018^{* * *} \\
(0.006)\end{array}$ & $\begin{array}{c}0.018^{* * *} \\
(0.006)\end{array}$ & $\begin{array}{l}0.011^{\text {** }} \\
(0.005)\end{array}$ \\
\hline MES & $\begin{array}{l}-0.190^{*} \\
(0.107)\end{array}$ & $\begin{array}{c}-0.231^{* *} \\
(0.101)\end{array}$ & & $\begin{array}{r}-0.155 \\
(0.108)\end{array}$ & $\begin{array}{c}-0.184 * \\
(0.102)\end{array}$ & \\
\hline ADV & $\begin{array}{r}-0.677 \\
(0.498)\end{array}$ & $\begin{array}{r}-0.635 \\
(0.481)\end{array}$ & $\begin{array}{l}-0.980^{*} \\
(0.503)\end{array}$ & $\begin{array}{r}-0.821 \\
(0.522)\end{array}$ & $\begin{array}{r}-0.787 \\
(0.502)\end{array}$ & $\begin{array}{l}-1.011^{*} \\
(0.526)\end{array}$ \\
\hline $\mathrm{R} \& \mathrm{D}$ & $\begin{array}{l}0.478 \\
(0.11)\end{array}$ & $\begin{array}{r}0.195 \\
(0.395) \\
\end{array}$ & $\begin{array}{r}0.632 \\
(0.391)\end{array}$ & $\begin{array}{c}0.680 * \\
(0.410)\end{array}$ & $\begin{array}{r}0.430 \\
(0.439) \\
\end{array}$ & $\begin{array}{c}0.715^{*} \\
(0.412)\end{array}$ \\
\hline $\mathrm{F}$ & $\begin{array}{c}0.209^{* * *} \\
(0.039)\end{array}$ & $\begin{array}{c}0.206^{* * *} \\
(0.037)\end{array}$ & $\begin{array}{c}0.220^{* * *} \\
(0.019)\end{array}$ & $\begin{array}{c}0.222^{* * *} \\
(0.042)\end{array}$ & $\begin{array}{c}0.216^{* * *} \\
(0.040)\end{array}$ & $\begin{array}{c}0.225^{* * *} \\
(0.042)\end{array}$ \\
\hline $\mathrm{CI}$ & $\begin{array}{r}-0.067^{* * *} \\
(0.011)\end{array}$ & $\begin{array}{r}-0.028 \\
(0.033)\end{array}$ & $\begin{array}{r}-0.067^{* * *} \\
(0.011)\end{array}$ & $\begin{array}{c}-0.066^{* * *} \\
(0.011)\end{array}$ & $\begin{array}{r}-0.047 \\
(0.036)\end{array}$ & $\begin{array}{r}-0.065^{* * *} \\
(0.011)\end{array}$ \\
\hline $\mathrm{CI}^{2}$ & & $\begin{array}{r}-0.010 \\
(0.008) \\
\end{array}$ & & & $\begin{array}{r}-0.004 \\
(0.009) \\
\end{array}$ & \\
\hline LP & $\begin{array}{c}0.022^{* * *} \\
(0.006)\end{array}$ & $\begin{array}{c}0.023^{* * *} \\
(0.005)\end{array}$ & $\begin{array}{c}0.019^{* * *} \\
(0.006)\end{array}$ & $\begin{array}{c}0.017^{* * *} \\
(0.006)\end{array}$ & $\begin{array}{c}0.018^{* * *} \\
(0.006)\end{array}$ & $\begin{array}{c}0.017^{* * *} \\
(0.006)\end{array}$ \\
\hline $\mathrm{EE}$ & $\begin{array}{r}-0.033^{*} \\
(0.18)\end{array}$ & $\begin{array}{r}-0.021 \\
(0.020)\end{array}$ & $\begin{array}{l}-0.033^{*} \\
(0.018)\end{array}$ & $\begin{array}{c}-0.043^{* *} \\
(0.020)\end{array}$ & $\begin{array}{r}-0.035 \\
(0.022)\end{array}$ & $\begin{array}{l}-0.039^{*} \\
(0.020)\end{array}$ \\
\hline Intercept & $\begin{array}{r}-0.033 \\
(0.024) \\
\end{array}$ & $\begin{array}{l}-0.051^{*} \\
(0.027)\end{array}$ & $\begin{array}{r}-0.021 \\
(0.023) \\
\end{array}$ & $\begin{array}{r}-0.031 \\
(0.025) \\
\end{array}$ & $\begin{array}{r}-0.037 \\
(0.027) \\
\end{array}$ & $\begin{array}{r}-0.021 \\
(0.024) \\
\end{array}$ \\
\hline Observations & 244 & 244 & 244 & 244 & 244 & 244 \\
\hline Overall $\mathrm{R}^{2}$ & 0.355 & 0.387 & 0.335 & 0.323 & 0.358 & 0.319 \\
\hline Wald (p) & 0.000 & 0.000 & 0.000 & 0.000 & 0.000 & 0.000 \\
\hline
\end{tabular}

Note: Estimation was performed using the program Stata version $13 .{ }^{* * *},{ }^{* *}$ and ${ }^{*}$ denote $\mathrm{p}<0.01$, $\mathrm{p}<0.05$ and $\mathrm{p}<0.1$ respectively. Standard errors are in parentheses.

Source: Authors' calculations

\footnotetext{
${ }^{6}$ MES variable was excluded in some specification to deal with possible multicollinearity problem, as $\mathrm{HHI}$ and MES variables were strongly correlated.
} 
Regardless of the model specification and the method used to measure market concentration, our main findings do not differ, which indicates the robustness of the results. Specifications using revenue-based Herfindahl Hirschman index have slightly better statistical properties. Overall coefficient of determination shows that the models $1-3$ explain between $33.5 \%$ and $38.7 \%$ of market profitability variation, compared to the alternative group of specifications (models 4-6), which explain between $31.9 \%$ and $35.8 \%$ of the variations. All specifications are statistically significant as a whole at $1 \%$ significance level, as evidenced by the p-values value of the Wald test.

Market concentration (HHI) is a statistically significant factor of market profitability at $1 \%$ significance level in all specifications, apart from specification 6 , where it is statistically significant at $5 \%$ level. The estimated coefficient values are stable in all specification, and the results are robust to the different measurements and specifications. The estimated values of market concentration parameter imply that the increase in market concentration increases the net profit margin on the market, all other things being equal.

The results presented in Table 2 indicate that, besides market concentration, market profitability is also determined by prevalent financing method of the market, capital intensity and labor productivity. It also depends, to some extent, on energy efficiency, economies of scale, advertising and research and development intensity. The financing method (F) of the companies in the market strongly positively affects market profitability, as evidenced by the coefficient estimates for the variable and their robust statistical significance. The more own capital on the market, the higher profit margin of the market is. Capital intensity (CI) also has a statistically significant negative impact on market profitability. Thereby, linear form of the variable appears to be superior to the quadratic one. Labor productivity has a robust and statistically significant positive impact on market profitability in all specifications.

Surprisingly, minimum efficient scale reduces market profitability, albeit the result is not robust in all specifications. Markets with higher advertising intensity were also shown to be less profitable, although the results are not significant in all specifications. Some specifications indicate that higher research and development activity on a market could be associated with higher market profitability. Finally, most specifications indicate that the more energy efficient markets are less profitable.

Although our results suggest that the increase in market concentration leads to the increase in market profitability, it remains unclear if this is the result of market power abuse. Following the approach of Demsetz (1973) in addressing this question, we determine differences between average net profit margin of four and eight largest companies in each relevant market (PR4, PR8) on one side, and average net profit margin of all the other companies in the same market on the other 
side. If the largest companies on the market collude and abuse market power, this would lead to the growth of market profitability and the increase product prices. Nevertheless, such situation will benefit smaller enterprises which would still be able to attain similar profit margins, taking advantage of increased prices. Market concentration should not affect the difference in in that case. In contrast, if the efficiency causes the increase in both market concentration and profitability, the largest companies will be significantly more profitable than the others and the increase in market concentration should increase the difference in profitability. We test these hypotheses on samples of 230 and 232 observations by estimating our base model using PR4 and PR8 as dependent variables and EC2SLS method and report the results in Table 3.

Table 3: Estimation results of the impact of market concentration on difference in profitability between the largest and other companies in the market

\begin{tabular}{|l|r|r|r|r|}
\hline \multirow{2}{*}{ Variable } & \multicolumn{3}{|c|}{ Difference in profitability } \\
\cline { 2 - 5 } & \multicolumn{2}{|c|}{ PR4 } & \multicolumn{2}{c|}{ PR8 } \\
\hline \multirow{2}{*}{ HHI } & $\begin{array}{r}0.026 \\
(0.027)\end{array}$ & & $(0.251$ & \\
\hline \multirow{2}{*}{ HHI $^{*}$} & & 0.047 & & 0.025 \\
\hline Observations & & $(0.025)$ & & $(0.019)$ \\
\hline Overall R & 232 & 232 & 230 & 230 \\
\hline
\end{tabular}

Note: Estimation was performed using the program Stata version $13 .{ }^{* *},{ }^{*}$ and denote $\mathrm{p}<0.0$ and $\mathrm{p}<0.05$ respectively. Standard errors are in parentheses. All variables of the base model were estimated, but only market concentration is reported in the table.

Source: Authors' calculations

Table 3 shows that the market concentration does not affect profitability differences, regardless of its measure or the measure of the difference in profit. Such results further support market power hypothesis. The results imply that collusion and general abuse of dominant position by the largest companies partially explain the increase of market profitability caused by the increased market concentration.

\section{Results and discussion}

The results presented in the previous section indicate that the impact of market concentration on market profitability is positive and statistically significant. Furthermore, the market concentration does not affect the difference between market leaders and other companies in terms of profitability. Such results support theoretical predictions of Structure-Conduct-Performance paradigm, as well as our 
initial hypothesis. However, there are other significant variables affecting market profitability, particularly: prevalent financing method on the market (F), capital intensity (CI) and labor productivity (LP). Furthermore, the results show that other variables could also affect market probability to a lesser extent: minimum efficient scale (MES), advertising intensity (ADV), research and development intensity $(R \& D)$ and energy efficiency $(E E)$.

Significantly positive impact of prevalent financing method (F) on market profitability could reflect the situation companies in Serbia face regarding the scarcity and costs of borrowed capital. Statistically significant negative relationship between capital intensity (CI) and market profitability could be explained with excessive capital allocation on many Serbian markets, which impairs the optimal capacity use, eventually reducing profitability. Such results support the theoretical predictions of Spence (1977). The positive impact of labor productivity implies that the markets in which the companies make better use of their human resources and in which production processes there are more value added activities, are on average more profitable.

The surprising negative impact minimum efficient on market profitability could be a result of an imprecise proxy measurement used. Another possible explanation is that the companies in Serbian manufacturing industry do business at suboptimal capacity, possibly due to domestic market size paired with insufficient export competitiveness. This is consistent with the results concerning capital intensity variable. Also surprising is statistically significant negative impact of advertising intensity on market profitability in some model specifications. This shows that benefits of advertising efforts on Serbian markets do not compensate the increased costs, ultimately reducing profitability, which could be the consequence of the intermediate position of Serbian economy within global value chains integration (Kastratovic, 2016). Namely, the producers of intermediate goods, who require relatively less advertising efforts compared to the producers of finals goods, are more competitive and hence more profitable, which is reflected by the results. The positive coefficient of the research and development intensity variable suggests that more innovative markets tend to be more profitable. Finally, the reason for the negative impact of energy efficiency could be that the industries which require less energy input rely more on labor, and thus have lower value added and lower profitability.

To summarize, the increase in market concentration reduces the intensity of the competition in Serbian manufacturing industry sector. Therefore, there is a possibility to enhance resource allocation efficiency by improving the efficiency of antitrust policy and influencing the structural factors of the manufacturing sector. The results indicate that market concentration, in general, positively affects market profitability, which is in line with industry level findings of Bhandari (2010) and Gallagher et al. (2015), as well as with firm level findings of McDonald (1999), Setiawan and Effendi (2016) and Škuflić et al. (2018). There are also idiosyncratic 
factors of the markets which determine particular market's profitability, which must be taken into account when drawing conclusions regarding anticompetitive behavior of the dominant companies.

\section{Conclusions}

This research examined the impact of market concentration on market profitability in the case of Serbian manufacturing industry sector. The results suggest that such impact is statistically significant and positive, which supports our initial hypothesis. Additionally, the empirical results support the traditional market power hypothesis. The research thus provides additional empirical evidence, useful for answering the question of market structure impact on performance, which is still controversial in the theory of industrial organization.

The main implication of the results is that the intensity of competition can be influenced by the policies affecting market structural factors, such as the prevention of excessive market concentration. This emphasizes the importance of the existence and efficient enforcement of antitrust and competition regulation, particularly in Serbia.

Besides, the results of this research imply that that greater reliance on borrowed results in significant reduction of market profitability within manufacturing industry. This suggests that financing business activities in this sector could be problematic. Improving the access to financial resources, which are necessary for investment, could therefore enhance market performances. Thereby, it is important to beware the optimal use of the industrial capacities, as the results show that excessive capital concentration and advertising efforts in markets reduce their financial performances and that the producers appear not to fully take advantage of the economies of scale. Finally, industrial restructuring towards more value added activities and the increase in productivity by modernizing production technology could improve industrial performances.

Main limitations of this research stem from the quality of data used in the analysis and the ensuing assumptions made regarding the variables operationalizations. Accounting data from financial statements is not the ideal input and the approximations we had to make, simplified the reality of the observed markets.

Future research analyzing this topic should include a sample with a longer time dimension which would allow the investigation of a dynamic relationship between market concentration and profitability. Additionally, analysis could be expanded to include foreign direct investment, which was shown to strongly interact with market concentration in comparable settings (Kastratović, 2018). Finally, it would be interesting to conduct a research on the impact of market concentration on profitability in other sectors, such as services, and examine possible differences in results. 


\section{References}

Alhassan, A.L., Addisson, G.K., Asamoah, M.E. (2015) "Market structure, efficiency and profitability of insurance companies in Ghana", International Journal of Emerging Markets, Vol. 10, No. 4, pp. 648-669, doi: 10.1108/ IJoEM-06-2014-0173.

Anderson, J.H., Lee, Y., Murrell, P. (2000) "Competition and privatization amidst weak institutions: evidence from Mongolia", Economic Inquiry, Vol. 38, No. 4, pp. 527-549, doi: 10.1111/j.1465-7295.2000.tb00034.x.

Bain, J.S. (1951) "Relation of Profit Rate to Industry Concentration: American Manufacturing, 1936-1940", The Quarterly Journal of Economics, Vol. 65, No. 3, pp. 293-324, doi: 10.2307/1882217.

(1956) Barriers to New Competition, Their Character and Consequences in Manufacturing Industries. Cambridge: Harvard University Press.

Baltagi, B. H. (1981) "Simultaneous equations with error components", Journal of Econometrics, Vol. 17, No. 2, pp. 189-200, doi: 10.1016/0304-4076(81)90026-9.

Bhandari, A.K. (2010) "Concentration, Entry Barriers and Profitability in the Indian Industries: An Empirical Analysis", Journal of Quantitative Economics, Vol. 8, No. 2, pp. 61-80.

Blažková, I., Dvouletý, O. (2017) "Is the price-cost margin affected by the market concentration? Evidence from the Czech food and beverages industry", Business and Economic Horizons, Vol. 13, No. 2, pp. 256-269, doi: 10.15208/ beh.2017.19.

Brozen, Y. (1971) "Concentration and structural and market disequilibria", Antitrust Bulletin, Vol. 16, pp. 241-248.

Cascorbi, A. (2003) Demerger-Management - Wertorientierte Desintegration von Unternehmen. Wiesbaden: Deutscher Universitäts-Verlag.

Clarke, R. (1984) "Profit margins and market concentration in UK manufacturing industry: 1970-6", Applied Economics, Vol. 16, No. 1, pp. 57-71, doi: 10.1080/ 00036848400000006.

Collins, N. R., Preston, L. E. (1969) "Price-Cost Margins and Industry Structure", The Review of Economics and Statistics, Vol. 51, No. 3, pp. 271-286, doi: $10.2307 / 1926562$.

Cowling, K., Waterson, M. (1976) "Price-Cost Margins and Market Structure", Economica, Vol. 43, No. 171, pp. 267-274, doi: 10.2307/2553125.

Demsetz, H. (1973) "Industry Structure, Market Rivalry, and Public Policy", The Journal of Law and Economics, Vol. 16, No. 1, pp. 1-9, doi: 10.1086/466752.

Foundation for the Advancement of Economics. (2013) "Policy Measures to Formalize the Shadow Economy and their Effects on Economic Growth in Serbia", Policy Brief [Internet], pp. 1-6. Available at: <https://www.fren.org.rs/ node/285?lang=en $>$ [Accessed: October 3, 2002]. 
Gal, M.S., Cheng, T.K. (2016) "Aggregate concentration: a study of competition law solutions", Journal of Antitrust Enforcement, Vol. 4, No. 2, pp. 282-322, doi: 10.1093/jaenfo/jnw004.

Gallagher, D. R., Ignatieva, K., McCulloch, J. (2015) "Industry concentration, excess returns and innovation in Australia", Accounting and Finance, Vol. 55, No. 2, pp. 443-466, doi: 10.1111/acfi.12074.

Hausman, J.A. (1978) "Specification Tests in Econometrics", Econometrica, Vol. 46, No. 6, pp. 1251-1271, doi: 10.2307/1913827.

Kastratović, R. (2016): "The influence of foreign direct investments on economic and social development of Serbia", Bankarstvo, Vol. 45, No. 4, pp. 70-93, doi: 10.5937/bankarstvo1604070K.

- (2018) "Foreign direct investment impact on market concentration in the manufacturing sector of Bosnia and Herzegovina", Facta Universitatis, Series: Economics and Organization, Vol. 15, No. 2, pp. 135-148, doi: 10.22190/ FUEO1802135K.

Keil, J. (2017) "Explaining the Concentration-Profitability Paradox", Review of Political Economy, Vol. 29, No. 2, pp. 209-231, doi: https://doi.org/10.1080/095 38259.2017.1295945.

(2018) "Is there a causal effect of concentration on persistent profitability differentials?", Industrial and Corporate Change, pp. 1-19, doi: 10.1093/icc/ dty014.

Khan, M.H., Hanif, M.N. (2018) "Empirical evaluation of 'structure-conductperformance' and 'efficient-structure' paradigms in banking sector of Pakistan", International Review of Applied Economics, pp. 1-15, doi: 10.1080/02692171. 2018.1518411.

Lee, C.Y., Mahmood, I.P. (2009) "Inter-industry differences in profitability: the legacy of the structure-efficiency debate revisited", Industrial and Corporate Change, Vol. 18, No. 3, pp. 351-380, doi: 10.1093/icc/dtp009.

Leibenstein, H. (1966) "Allocative Efficiency vs. X-Efficiency", The American Economic Review, Vol. 56, No. 3, pp. 392-415.

Li, Y., Nie, D., Zhao, X., Li, Y. (2017) "Market structure and performance: An empirical study of the Chinese solar cell industry", Renewable and Sustainable Energy Reviews, Vol. 70, pp. 78-82, doi: 10.1016/j.rser.2016.11.064.

Lončar, D., Đorđevic, A., Lazić, M., Milošević, S., Rajic, V. (2016) “Interplay between market concentration and competitive dynamics in the banking sector: Evidence from Serbia, Croatia, Romania and the Czech Republic", Ekonomika preduzeća, Vol. 64, No. 5-6, pp. 332-346, doi: 10.5937/ekopre 16063321.

Mason, E.S. (1939) "Price and Production Policies of Large-Scale Enterprise", The American Economic Review, Vol. 29, No. 1, pp. 61-74. 
McDonald, J.T. (1999) "The Determinants of Firm Profitability in Australian Manufacturing", Economic Record, Vol. 75, No. 2, pp. 115-126, doi: 10.1111/ j.1475-4932.1999.tb02440.x.

Mishra, P. (2008) "Concentration-Markup Relationship in Indian Manufacturing Sector", Economic and Political Weekly, Vol. 43, No. 39, pp. 75-81.

Mukhopadhyay, J., Chakraborty, I. (2017) "Competition and Industry Performance: A Panel VAR Analysis in Indian Manufacturing Sector", Journal of Quantitative Economics, Vol. 15, No. 2, pp. 343-366, doi: 10.1007/s40953-016-0055-2.

Outreville, J.F. (2015) "The market structure-performance relationship applied to the Canadian wine industry", Applied Economics Letters, Vol. 22, No. 18, pp. 1486-1492, doi: 10.1080/13504851.2015.1042133.

Pervan, M., Mlikota, M. (2013) "What Determines The Profitability of Companies: Case of Croatian Food and Beverage Industry", Economic Research/Ekonomska Istraživanja, Vol. 26, No. 1, pp. 277-286, doi: 10.1080/1331677x.2013.1151760.

Schmalensee, R. (1989) "Inter-industry studies of structure and performance". In: Schmalensee, R.,Willig, R. eds.: Handbook of Industrial Organization. $2^{\text {nd }}$ vol. Elsevier, doi: 10.1016/s1573-448x(89)02004-2.

Setiawan, M., Effendi, N. (2016) "Survey of the Industrial Concentration and Pricecost Margin of the Indonesian Manufacturing Industry", International Economic Journal, Vol. 30, No. 1, pp. 123-146, doi: 10.1080/10168737.2015. 1136666.

Stiegert, K. W., Wang, S. S., Rogers, R. T. (2009) "Structural change and market power in the U.S. food manufacturing sector", Agribusiness, Vol. 25, No. 2, pp. 164-180, doi: 10.1002/agr.20193.

Stojanović, B., Kostić, M. (2013) "Competition policy and the impact of market structure on companies' profitability", Ekonomika preduzeća, Vol. 61, No. 5-6, pp. 325-338, doi: 10.5937/ekopre1306325s.

Strickland, A. D.,Weiss, L. W. (1976) “Advertising, Concentration, and Price-Cost Margins", Journal of Political Economy, Vol. 84, No. 5, pp. 1109-1121. 8, doi: $10.1086 / 260499$.

Škuflić, L.,Mlinarić, D., Družić, M. (2018) "Determinants of construction sector profitability in Croatia", Zbornik radova Ekonomskog fakulteta u Rijeci, Vol. 36, No. 1, pp. 337-354, doi: 10.18045/zbefri.2018.1.337.

Spence, M.A. (1977) "Entry, Capacity, Investment and Oligopolistic Pricing", The Bell Journal of Economics, Vol. 8, No. 2, pp. 534-544, doi: 10.2307/3003302.

Vives, X. (2008) "Innovation and Competitive Pressure", Journal of Industrial Economics, Vol. 56, No. 3, pp. 419-469, doi: 10.1111/j.1467-6451.2008.00356.x.

Willis, M.S., Rogers, R.T. (1998) "Market share dispersion among leading firms as a determinant of advertising intensity", Review of Industrial Organization, Vol. 13, No. 5, pp. 495-508, doi: 10.1023/a:1007704811420. 


\title{
Tržišna koncentracija i profitabilnost: Empirijski dokazi iz prerađivačke industrije Srbije ${ }^{1}$
}

\author{
Radovan Kastratović ${ }^{2}$, Dragan Lončar ${ }^{3}$, Siniša Miloševic ${ }^{4}$
}

\begin{abstract}
Sažetak
Utjecaj tržišne koncentracije na profitabilnost je kontroverzno pitanje u oblasti industrijske organizacije, na koje nema jasnog odgovora. Cilj istraživanja je ispitati ovaj eventualni utjecaj u kontekstu prerađivačke industrije Srbije. Temeljna hipoteza u ovom istraživanju jest da povećanje koncentracije tržišta povećava profitabilnost na tržištima zbog tajnog sporazuma dominantnih tvrtki. Hipoteza je testirana definiranjem i ocjenom modela koji opisuje utjecaj strukturnih i ostalih kontrolnih varijabli na profitabilnost tržišta, korištenjem sekundarnih podataka panela za 122 tržišta, promatrana u 2015. i 2017. godini. Podaci su dobiveni iz 30037 financijskih izvješća tvrtki iz sektora prerađivačke industrije. Model je procijenjen primjenom dvostupanjske metode najmanjih kvadrata s komponentama slučajne pogreške (EC2SLS). Rezultati istraživanja ukazuju na statistički značajan pozitivan utjecaj koncentracije tržišta na profitabilnost, što ide u prilog tradicionalnoj hipotezi tržišne snage.
\end{abstract}

Ključne riječi: tržišna koncentracija, profitabilnost, konkurencija, tajni sporazum, prerađivačka industrija

JEL klasifikacija: D43, L11, L41

1 Autori izjavljuju da nemaju relevantnih ili materijalnih financijskih interesa koji se odnose na istraživanje opisano u ovom radu.

Zahvale: Želimo se zahvaliti uredniku i anonimnim recenzentima na korisnim komentarima i sugestijama. Također, zahvaljujemo se profesoru Goranu Petkoviću na sugestijama, kojima je poboljšana ranija verzija ovog rada. Za sve eventualne pogreške odgovornost snose isključivo autori.

${ }^{2}$ Analitičar, Institut za poslovna istraživanja-MBA, Dubrovačka 24, 11000 Beograd, Srbija. Znanstveni interes: međunarodna ekonomija, industrijska organizacija. Tel.: +381 11203 0002. Fax: +381112928015.E-mail: radovan.kastratovic@institutmba.co.rs. Osobna web stranica: https://www.institutmba.co.rs/ (osoba za kontakt).

${ }^{3}$ Redoviti profesor, Ekonomski fakultet, Univerzitet u Beogradu, Kamenička 6, 11000 Beograd, Srbija. Znanstveni interes: strateški menadžment, projektni menadžment, konkurencija. Tel.: +381 11302 1075. E-mail: loncar@ekof.bg.ac.rs. Osobna web stranica: http://www.ekof. bg.ac.rs/loncar-dr-dragan/.

${ }^{4}$ Glavni ekonomist, Komisija za zaštitu konkurencije Republike Srbije, Savska 25, 11000 Beograd, Srbija. Znanstveni interes: konkurencija, industrijska organizacija. E-mail: sinisa. milosevic@kzk.gov.rs. Osobnawebstranica: http://www.kzk.org.rs/. 
